\title{
The Effect of Using Different Size Purple Carrots and Lactobacillus Plantarum on the Properties of Fermented Shalgam (Şalgam)
}

\author{
Hasan Tangüler ${ }^{1, a, *}$ \\ ${ }^{I}$ Department of Food Engineering, Ömer Halisdemir Niğde University, 51240 Niğde, Turkey \\ *Corresponding author

ARTICLE INFO ABSTRACT \\ Research Article \\ Şalgam (Shalgam) beverage, which is manufactured by lactic acid-ethanol fermentation, takes its \\ name from turnip radish and its purple-reddish colour from purple carrot, is a drink with certain \\ turbidity and sour taste. This research was carried out to determine the effect of using an \\ autochthonous starter culture and purple carrot size in şalgam production. For this purpose, with the \\ Received : 03/02/2021 \\ Accepted : 22/04/2021 \\ direct production process, purple carrot in two different sizes $(4 \mathrm{~cm}$ horizontally cut purple carrot \\ or $12 \mathrm{~cm}$ vertically cut purple carrot) and şalgam with the addition of $3 \%$ L. plantarum was \\ produced. The added starter culture enabled the fermentation to start quickly and the maximum total \\ acidity and LAB count was reached earlier. Besides, the addition of starter culture significantly \\ affected the overall composition of şalgam. In the production of shalgam beverage, the use of \\ Keywords: \\ Shalgam beverage \\ Purple carrot \\ horizontally cut purple carrot and L. plantarum as an autochthonous starter culture can be \\ recommended.
} Size

Autochthonous

Starter culture

\section{Introduction}

Fermentation, one of the oldest ways to preserve raw foods with low shelf life, is a low-energy preservation method and one of the most important technologies in food manufacture (Mishra et al., 2017; Veiga et al., 2019; Ignat et al., 2020). However, it is the simplest, cheapest, most economical and reliable way to increase the nutritional value, functional properties, durability and sensory properties of food-beverages (Blandino et al., 2003; Baschali et al., 2017). Therefore, fermented foods and beverages universally play a very important role in people's diet due to their positive impacts on health (Naidu et al., 1999; Garcia et al., 2020). Lots of research has been done on important internationally recognized industrial fermented products such as cheese, pickles, olives, wine and beer (Tangüler and Ağırman, 2020; Baschali et al., 2017). However, although the number of studies on local products has started to increase recently, there is still a lot of research to be done. There are various traditional fermented beverages in Turkey such as ayran (Köksoy and Kılıç, 2004), boza (bousa, bozas, busa, busaa), şalgam (fermented carrot juice), hardaliye and gilaburu (gilaboru, gileboru, gileburu, gulebru, girebolu) (Kabak and Dobson, 2011).
Şalgam, one of these products, is produced by using basic raw materials such as purple (black) carrots (anthocyanin category, "Daucus carota ssp. sativus var. atrorubens Alef.") as well as setic (crushed wheat, bulgur flour), turnip radish ("Brassica rapa L."), rock-salt and potable water. Shalgam is a fermented beverage with a turbid and sour taste, which is obtained by mixing the raw materials specified following the technique and leaving them to fermentation. This beverage is extensively produced and consumed in the cities of Adana, Hatay and Mersin and the districts, villages and towns of these cities. In recent years, especially in large cities such as İstanbul, Ankara, Konya and İzmir and also it has become popular in all of Turkey (Tangüler and Erten, 2012; Altay et al., 2013; Tangüler et al., 2020).

Şalgam is a small-scale product that is produced at home, even if it used to be and partially today. However, with the recent increase in consumption, commercial production has become an important industrial product. With this increase, the consumption amount reached at least the level of other beverages. The most important reason for this is that şalgam can be consumed in harmony with local foods (such as Adana kebab, lahmacun, cabbage pickles, various pitas and 
meatballs) and beverages (such as Rak1) and complement them in terms of taste (Erten et al., 2008; Kabak and Dobson 2011; Tangüler and Ağırman, 2020).

There is no standard production process known and currently used in Turkey in the production of şalgam, and the production carried out on an industrial scale varies from company to company (Erten et al., 2008; Tangüler, 2010). However, two different processes are used in the production. The first, and more often preferred, of these is the traditional (two-step) process. In this process, setic, bread yeast or sourdough and salt are brought to a dough consistency with a sufficient amount of potable water. The dough obtained is left to the lactic acid fermentation for at least 3 days. At the end of fermentation, the fermented pulp is extracted with water and the extract containing a significant amount of lactic acid bacteria (LAB) is used to start the carrot (basic) fermentation, also is called the second fermentation. In the second fermentation, at least $15 \%$ of the main raw material (purple carrots), as well as rock salt and water, are used. On the other hand, although it gives the şalgam its name, it is not generally used in turnip radish production. However, if it can be obtained in some productions or if desired, cleaned and sliced turnip radish are also used. The second method used in production is the direct (direct or slow) production of şalgam. The main difference from the traditional process is that dough fermentation is not utilized. All raw ingredients to be utilized in manufacture are transferred to the tank and the necessary amount of water is added and the main (carrot) is left to fermentation to produce şalgam (Erten and Tangüler, 2012; Tangüler and Erten, 2013; Tangüler and Ağırman, 2020).

Unfortunately, there is no use of any starter culture isolated from şalgam or other media in the şalgam production (Tangüler et al., 2020). Although LAB such as Lactobacillus (L.) plantarum as well as yeast (Saccharomyces, S., cerevisiae etc.) Are present and effective in şalgam fermentation, it is generally known as a lactic acid fermentation product (Canbaş and Fenercioğlu 1984; Çakır, 2011; Bircan, 2013). In the studies carried out, the bacteria that are frequently isolated and identified from şalgam are L. plantarum, L. fermentum and L. paracase (Arıc1, 2004; Erginkaya and Hammes, 1992; Tangüler and Erten, 2013). However, in a study carried out, it was reported that $L$. plantarum was the most isolated LAB in şalgam produced in the laboratory by traditional process or direct process and şalgam supplied from companies producing industrial scale (Tangüler, 2010). Therefore, $L$. plantarum (Barath et al., 1999; Tangüler, 2010), which is LAB resistant to high acidity and which is frequently used in vegetable fermentation, was preferred as the starter culture to be used in this study.

Besides, some producers use purple carrot in different ways in the production of şalgam. Some producers use it in fermentation by cutting vertically and the fermented carrots obtained at the end of fermentation (named as grain, grain in Adana and nearby regions) are served to consumers as in open (without bottle) the şalgam. Therefore, the size of the carrot, another important parameter in the şalgam production, was evaluated within the scope of this study. As a result, the research aims to determine the impact of adding different sizes of purple carrots in the şalgam production using L. plantarum.

\section{Material and Method}

\section{Material}

Among the raw materials utilized in the manufacture of şalgam, purple carrot, setic and rock salt were obtained from the İcenbilir Hacının Şalgamı company. While total sugar in purple carrot was determined as $7.38 \mathrm{~g} / 100 \mathrm{~g}$ and titratable acidity as $2.26 \mathrm{~g} / 100 \mathrm{~g}$ (as lactic acid), these values were determined as $2.36 \mathrm{~g} / 100 \mathrm{~g}$ and $1.6 \mathrm{~g} / 100 \mathrm{~g}$, respectively, in setic. On the other hand, bread yeast was purchased from the local market and turnip radish was purchased from a vegetable market (Adana, Turkey).

As an autochthonous starter culture, in the study conducted by Tangüler (2010) L. plantarum isolated from şalgam was used. For this purpose, L. plantarum was obtained as a single colony on MRS agar medium (Merck, Darmstadt, Germany). It was taken from this single colony and again planted in MRS agar and two colonies were taken and inoculated into $500 \mathrm{~mL}$ flasks containing $400 \mathrm{~mL}$ pasteurized carrot juice. After 2 days of incubation at $25^{\circ} \mathrm{C}$, pure L. plantarum culture was taken at a rate of $3 \%(\mathrm{v} / \mathrm{v})$ and transferred to glass carboys.

\section{Method}

Purple carrots supplied from the supplier company to produce şalgam were brought to "the Industrial Microbiology Laboratory of Çukurova University Food Engineering Department (Adana, Turkey)" and sorted into 2 groups. Purple carrots below $12 \mathrm{~cm}$ were included in the first group and long purple carrots required for vertical cutting were included in the second group. Purple carrots in the first group were cut into $4 \mathrm{~cm}$. The purple carrots in the second group were first cut to $12 \mathrm{~cm}$ in size and divided vertically into two. Turnip radishes were similarly brought to the laboratory, sorted and cut into thin slices. The production was carried out with the direct production process (Figure 1). The trial pattern is planned as follows. $\mathrm{S} 1(4 \mathrm{~cm}$ horizontally cut purple carrot $+30 \mathrm{ml} / \mathrm{L} \mathrm{L}$. plantarum), $\mathrm{S} 2$ (12 cm vertically cut purple carrot $+30 \mathrm{ml} / \mathrm{L}$ L. plantarum $)$, $\mathrm{K}$ (Control, $75 \mathrm{~g} / \mathrm{L}$ horizontally cut purple carrot $4 \mathrm{~cm}$ in size) $+75 \mathrm{~g} / \mathrm{L}$ purple carrot $12 \mathrm{~cm}$ vertically cut).

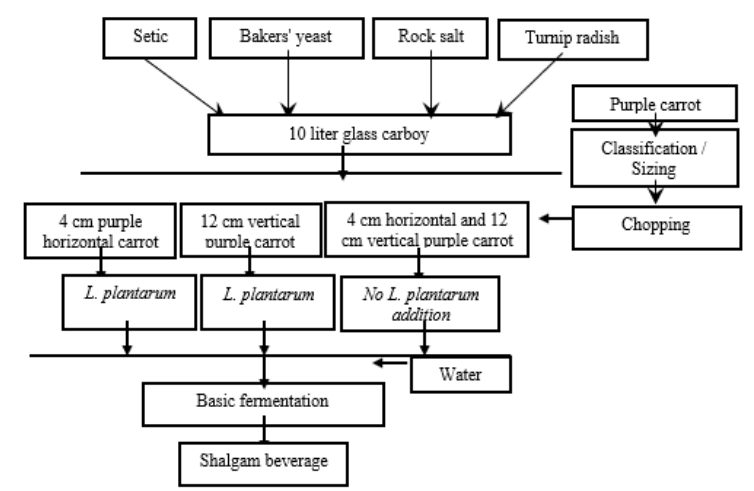

Figure 1. Direct (without fermentation of dough) şalgam production process (Erten et al., 2008)

For the production of şalgam beverage, $30 \mathrm{~g} / \mathrm{L}$ cetic, 12 $\mathrm{g} / \mathrm{L}$ rock-salt, $10 \mathrm{~g} / \mathrm{L}$ thinly cut turnip radish and directly 2 $\mathrm{g} / \mathrm{L}$ baker's yeast and $30 \mathrm{ml} / \mathrm{L}$ autochthonous starter culture (L. plantarum) were added to 10-litre glass carboys (Figure 1). Also, $150 \mathrm{~g} / \mathrm{L}$ of the horizontally cut purple carrots (S1) of $4 \mathrm{~cm}$ or the vertical cut purple carrots $(\mathrm{S} 2)$ of $12 \mathrm{~cm}$ was 
added to the tank. The trial without $L$. plantarum was used as a control $(75 \mathrm{~g} / \mathrm{L}$ purple carrots $4 \mathrm{~cm}$ horizontally cut + $75 \mathrm{~g} / \mathrm{L}$ purple carrots $12 \mathrm{~cm}$ longitudinally cut. After the addition of raw materials, the glass carboy was completed with drinkable water and left to fermentation in the fermentation room at $25^{\circ} \mathrm{C}$. Trials for the manufacture of şalgam were established in two parallel and the progress of the fermentation was followed by the acidity analysis.

\section{Microbiological Analysis}

The samples of şalgam were taken from the middle of the glass jar and consecutive dilutions were arranged in dilution liquid $(0.85 \% \mathrm{w} / \mathrm{v})$. Microbiological analyzes were performed using these dilutions. Plate count agar (Merck, Darmstadt, Germany) utilized for enumeration of total mesophilic aerobic bacteria at $30^{\circ} \mathrm{C}$ (Halkman, 2005), de Man Ragosa Sharpe (MRS, Merck, Darmstadt, Germany) agar was used for the count of LAB at $30^{\circ} \mathrm{C}$ is, violet red agar (Merck, Darmstadt, Germany) was used for count of coliform bacteria even at $30^{\circ} \mathrm{C}$ (Gassem, 2002; Halkman, 2005). Besides, total yeast count was determined using malt extract agar (Merck, Darmstadt, Germany) at $25^{\circ} \mathrm{C}$. (Halkman, 2005).

\section{General Analysis}

Dry matter, ash, titratable acidity and total sugar were determined in purple carrots and set used for the şalgam production. Dry matter $(\mathrm{g} / \mathrm{L})$, ash $(\mathrm{g} / \mathrm{L}), \mathrm{pH}$, titratable acidity (g/L, expressed as lactic acid), volatile acidity $(\mathrm{g} / \mathrm{L}$, expressed as acetic acid), total sugar $(\mathrm{mg} / \mathrm{L})$, salt $(\mathrm{g} / \mathrm{L})$, total phenol $\left(\mathrm{OY}_{280}\right)$ and anthocyanin $(\mathrm{mg} / \mathrm{L})$ were determined in the şalgam beverages. Dry matter, ash, $\mathrm{pH}$ and total acidity determinations in the samples were determined according to AOAC (1990). Total acidities were assigned by using N/10 sodium hydroxide and the results are given in terms of lactic acid (Tangüler, 2010). The salt determination was obtained by titration method with N/10 silver nitrate solution (Aktan et al., 1998) and total sugar values were determined using the method reported by researchers such as Catley (1988) and Amrane and Prigent (1996). The determination of volatile acid was determined according to the steam distillation method (Ough and Amerine, 1988; AOAC, 1990). To determine total phenol results, each beverage produced were first clarified by centrifugation and the OY 280 value was determined using spectrophotometer cuvettes. The results are given as index $\mathrm{OY}_{280}$ (Ribereau-Gayon et al., 2006). The different $\mathrm{pH}$ method was used for total anthocyanin analysis. The samples clarified by centrifugation were mixed with $\mathrm{pH}$ : 4.5 and $\mathrm{pH}$ : 1 buffer solutions and absorbance values were determined at $510 \mathrm{~nm}$ and $700 \mathrm{~nm}$ in the spectrophotometer. The total anthocyanin value was given in terms of cyanidin-3-glycoside (Wrolstad, 1976). Production trials and analyzes were carried out in two parallel.

\section{Statistical Analysis}

The obtained data were evaluated according to a oneway analysis of variance and Duncan multiple comparison tests was applied to determine the difference between groups. The t-test was used to compare pairs of groups $(n=2)$. For this purpose, the SPSS 18.0 Statistical Package Program was used.

\section{Result and Discussion}

Titratable Acidity-pH Change During Fermentation

Variation of titratable acidity and $\mathrm{pH}$ during fermentation carried out to produce şalgam beverage is given in Figure 2.

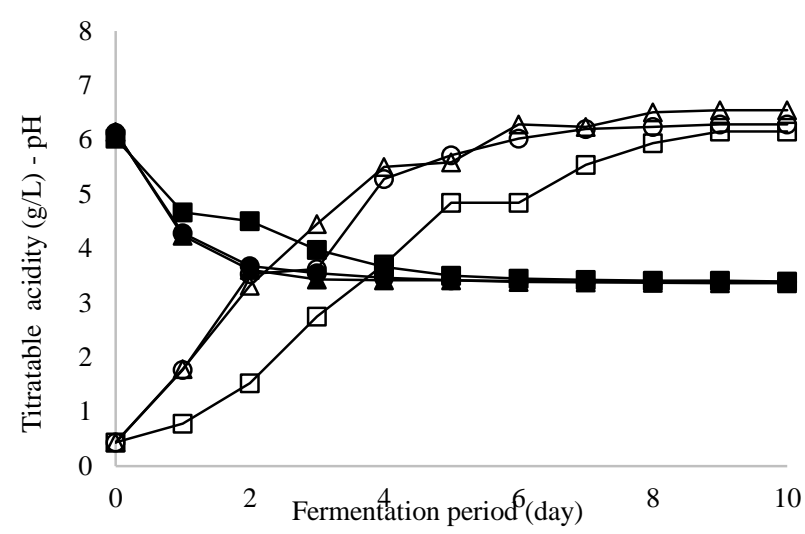

Figure 2. Process of fermentation during şalgam production

--口--: K, titratable acidity, -----: K, pH, -- $\Delta$--: S1, titratable acidity, -- $\boldsymbol{\Delta}$ -: S1, pH, --०--: S2, titratable acidity, --•--; S2, pH

As can be seen from the Figure, the titratable acidity values at the beginning of the fermentation are $0.44 \mathrm{~g} / \mathrm{L}$ and the $\mathrm{pH}$ values vary between 6.02 and 6.15 . With the start of fermentation, the experiments in which L. plantarum culture was added increased rapidly until the 6th day and then the increase rate decreased. However, a slower increase was observed with the start of fermentation in the control sample compared to the experiments using $L$. plantarum culture. A similar difference was also observed in the $\mathrm{pH}$ value. In the experiments using L. plantarum, the decrease in $\mathrm{pH}$ value was faster. The most important reason for this is thought to be L. plantarum added to the medium at the beginning of fermentation. At the end of fermentation, the highest total acidity in terms of lactic acid was obtained with $6.55 \mathrm{~g} / \mathrm{L}$ in the $\mathrm{S} 1$ experiment, while the lowest value was determined with $6.16 \mathrm{~g} / \mathrm{L}$ in the control experiment. On the other hand, the highest $\mathrm{pH}$ was obtained in the control trial with 3.40 and the lowest in the S1 trial with $\mathrm{pH} 3.37$.

According to the TS 11149 standard in Turkey, it is reported that the amount of titratable acid (as lactic acid) in şalgam should be $6 \mathrm{~g} / \mathrm{L}$ or higher per litre of the product, and the $\mathrm{pH}$ value should be between 3.3-3.8. (TSE, 2003). Therefore, it can be stated that turnip drinks in different sizes produced in the laboratory with $L$. plantarum and without $L$. plantarum comply with TSE (2003) standards. On the other hand, statistically, the difference between samples in terms of total acidity and $\mathrm{pH}$ was found to be significant (Table 1) $(\mathrm{P} \leq 0.05)$.

At the beginning of fermentation, $\mathrm{pH}$ values were determined between 3.16-5.9 and total acidity values between $0.2-2.4 \mathrm{~g} / \mathrm{L}$ in şalgams produced by the traditional method. In addition, at the end of fermentation, $\mathrm{pH}$ values were found between 3.28-3.67 and total acidity values were between 6.67-7.45 g/L (Canbaş ve Deryaoğlu, 1993; Arıc1; 2004; İyiçınar, 2007; Güneş, 2008; Tangüler, 2010; Cankaya, 2018). However, Utuş (2008) found $\mathrm{pH}$ values between 6.05-6.27 and total acidity amounts between 0.48 - 
$0.6 \mathrm{~g} / \mathrm{L}$ at the beginning of fermentation in her study in which she investigated the impact of different purple carrot sizes on some characteristics of şalgams manufactured by traditional process. Besides, at the end of fermentation, it has determined between 3.45-3.53 and 7.15-7.75 g/L, respectively.

In a study made by Tangüler (2010) using different production methods and autochthonous starter culture, the $\mathrm{pH}$ value at the beginning of fermentation in şalgams was determined between 4.07 and 5.46 and the total acid amount between $0.73-2.28 \mathrm{~g} / \mathrm{L}$. Also, it was determined between 3.42-3.55 and 6.33-9.22 $\mathrm{g} / \mathrm{L}$ at the end of fermentation, respectively. On the other hand, he reported that the lowest total acidity was obtained in the direct manufacturing process. Besides, it has been reported that $\mathrm{pH}$ values at the beginning of fermentation are between 2.76-7.75 and total acidity values are between $0.1-6.13 \mathrm{~g} / \mathrm{L}$ in studies conducted with the direct production process. Moreover, at the end of fermentation, these values have been reported to be between 3.36-3.46 and 6.83-7.25 g/L, respectively (Tangüler, 2010; Cankaya, 2018).

While the data obtained in the study carried out are generally compatible with previous studies (Tangüler, 2010; Cankaya, 2018) on the direct production process, it is lower than the values determined in the şalgams obtained in the trials performed using the traditional process. The most important reason for this is thought to be the dough fermentation performed in the traditional process. However, the addition of starter culture causes a significant increase in total acidity, while the size of carrots used causes a slight change. Beverages produced with horizontally cut carrots were found to have a slightly higher acidity.

\section{Changes in Microorganisms During Fermentation}

The Count of Lactic Acid Bacteria

LAB is of great importance in terms of food and beverage technology. Fermented milk products, fermented herbal products, cereal products, meat products as well as many foods or beverages such as wine, beer, fish sauce have positive effects on the production and enhancement of their durability (Caplice and Fitzgerald, 1999; Blandio et al., 2003). Among the LAB that is effective in the fermentation of various herbal products, those belonging to the Lactobacillus genus, which has the largest group, have an important place. Especially L. plantarum is among the bacteria that are effective in vegetable fermentation, are industrially very important and resistant to high acidity and generally become dominant during fermentation and terminate the fermentation (Tangüler, 2010). The change in the number of LABs during the production of şalgam is given in Figure 3.

As can be seen from Figure 3, the number of LAB at the beginning of fermentation varies between 6.9 and 7.6 $\log \mathrm{CFU} / \mathrm{mL}$. With the onset of fermentation, a rapid increase was observed in the experiments with $L$. plantarum until the fourth day, and they reached the levels of $8.4 \log \mathrm{CFU} / \mathrm{mL}$ in the $\mathrm{S} 1$ trial and $8.2 \log \mathrm{CFU} / \mathrm{mL}$ in the $\mathrm{S} 2$ trial. In contrast, a slight lag phase was observed in the control trial, and then LAB numbers increased until the fifth day. On the other hand, in all trials, LAB numbers decreased after reaching the maximum level and were determined between $6.9 \log \mathrm{CFU} / \mathrm{mL}$ and $7.21 \mathrm{log}$ $\mathrm{CFU} / \mathrm{mL}$ at the end of fermentation.
Tangüler (2010) determined the number of LAB at the beginning of fermentation between 3.3-6.3 log CFU/mL, and at the end of fermentation between 5.5-7.7 $\log \mathrm{CFU} / \mathrm{mL}$ in şalgams procured by direct production processes. Moreover, in şalgams produced under laboratory conditions, $7.71 \log \mathrm{CFU} / \mathrm{mL}$ at the beginning and $7.4 \log \mathrm{CFU} / \mathrm{mL}$ at the end. In the study conducted by Çankaya (2018), it was reported that it was between 5.65-7.19 $\log \mathrm{CFU} / \mathrm{mL}$ at the beginning of fermentation and between 7.63 and $8.33 \mathrm{log}$ $\mathrm{CFU} / \mathrm{mL}$ at the end of fermentation. On the other hand, in other studies conducted on şalgam using traditional processes, the LAB number was found between 3.32-9.19 $\log \mathrm{CFU} / \mathrm{mL}$ before fermentation and between 2.18-8.95 log CFU/mL after fermentation (Güneş, 2008; Öztürk, 2009; Çakır, 2011; Ağırman, 2014; Gök, 2017). The LAB numbers obtained in the trial carried out are generally compatible with the values reported by the previous researchers (Güneş, 2008; Öztürk, 2009; Çakır, 2011; Ağırman, 2014; Gök, 2017), and there is a very slight elevation only in the S2 trial.

The Count of Total Mesophilic Aerobic Bacteria

Total mesophilic aerobic bacteria numbers are a significant criterion that is frequently evaluated as it is a criterion used as an indicator for microbial quality in foods. It is one of the indicators of compliance with hygienic conditions especially in production, storage and transportation (Doğan and Tükel, 2000). The change in the total number of mesophilic aerobic bacteria during the manufacture of şalgam is given in Figure 4.

With the onset of fermentation, there was a rapid rise in the total number of mesophilic aerobic bacteria, and after reaching the maximum levels on the fourth day ( $\mathrm{S} 1$ on the fifth day), it decreased over time. It was determined between $6.1(\mathrm{~S} 1)$ and $6.6(\mathrm{~K}) \log \mathrm{CFU} / \mathrm{mL}$ at the end of fermentation. According to the TS 11149 standard, it is reported that the total number of mesophilic aerobic bacteria in şalgams should be between 4.0-5.0 log CFU/mL (TSE, 2003). It has been reported that the total number of mesophilic aerobic bacteria in şalgams produced by the direct production process is between 6.5-7.2 $\log \mathrm{CFU} / \mathrm{mL}$ at the beginning of fermentation and between 7.0-8.31 $\log \mathrm{CFU} / \mathrm{mL}$ at the end of fermentation (Tangüler, 2010; Çankaya, 2018). While the data obtained in the study performed is higher than TSE (2003), it is compatible with the values reported by Tangüler (2010) and Çankaya (2018).

\section{The Count of Total Yeast}

Yeasts are eukaryotic creatures that are widely found in nature and are important because they are effective in the fermentation of various fermented food and beverages (Tangüler, 2010). The change in the total number of yeast during the production of şalgam is given in Figure 5. As can be seen from the figure, the total yeast number determined at close values at the beginning of fermentation and between 7.6 and $7.7 \log \mathrm{CFU} / \mathrm{mL}$ increased over time. And then decreased rapidly after reaching the maximum number in all trials. At the end of fermentation, the total yeast number was determined between 6.05-6.54 log CFU/mL.

Tangüler (2010) determined the number of LAB at the beginning of fermentation between 5.6-7.2 $\log \mathrm{CFU} / \mathrm{mL}$ and, 6.2-6.3 $\log \mathrm{CFU} / \mathrm{mL}$ at the end of the fermentation for şalgams procured by direct production processes. Besides, in the study conducted by Çankaya (2018), it was reported that it was between $6.0-6.86 \log \mathrm{CFU} / \mathrm{mL}$ at the beginning of fermentation and between 6.86 and $8.04 \log \mathrm{CFU} / \mathrm{mL}$ at the end of fermentation. 


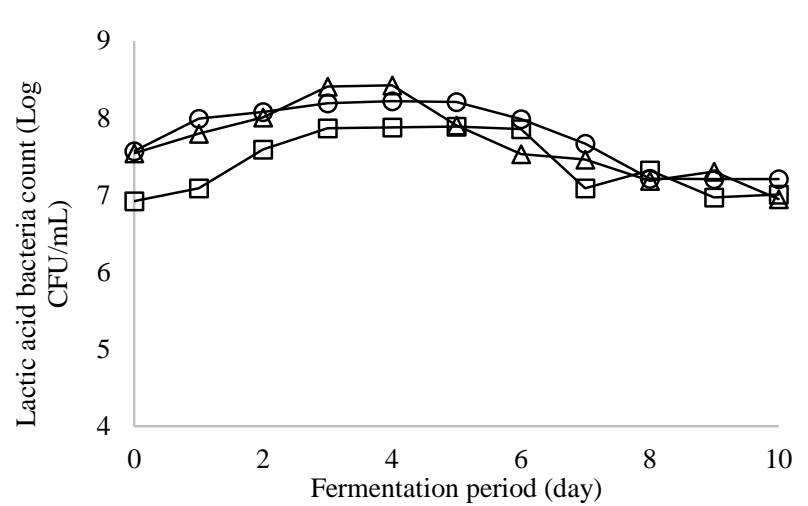

Figure 3. Change in the number of lactic acid bacteria --口--: K, -- $\Delta--:$ S1, --০--: S2

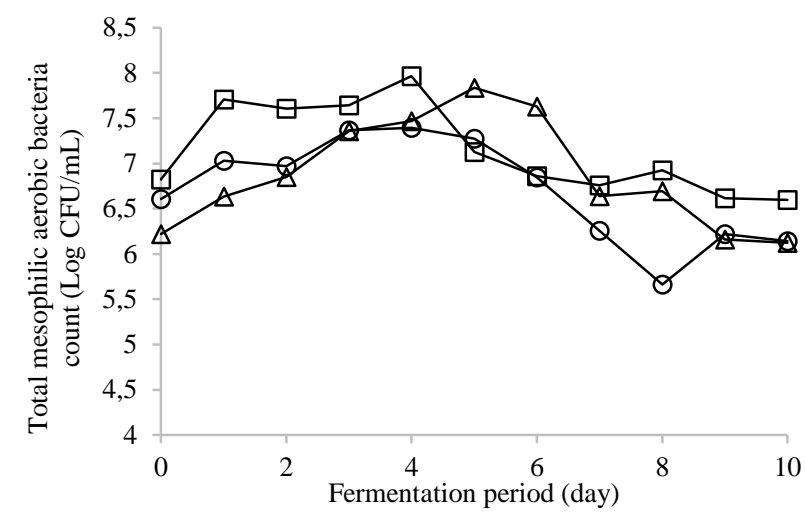

Figure 4. Change in total mesophilic aerobic bacteria number

--口--: K, -- $\Delta--:$ S1, --০--: S2

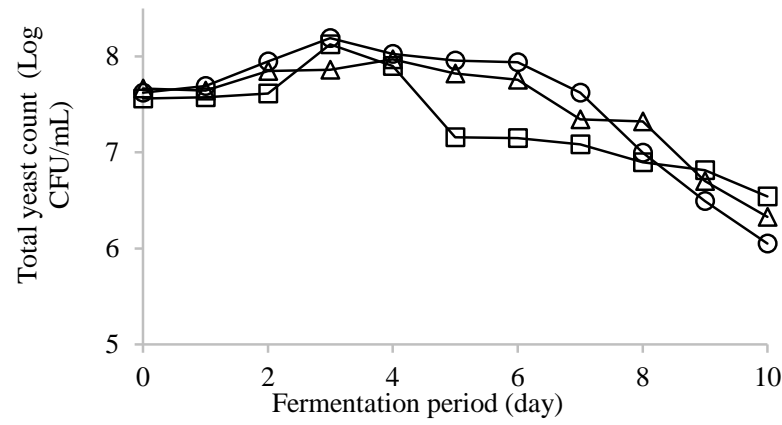

Figure 5. Change in total yeast count

$$
\text { --口--: K, -- } \Delta--: \text { S1, --o--: S2 }
$$

On the other hand, in other studies conducted on şalgam using traditional processes, total yeast counts were found between 5.5-7.6 $\log \mathrm{CFU} / \mathrm{mL}$ in ready-to-eat products (Özhan, 2000; Aydar, 2003; Güneş, 2008; Utuş, 2008). The data obtained in the study we conducted with the total number of yeasts determined in the beverages obtained in the studies conducted with both direct and traditional processes regarding the şalgam are generally compatible. However, the values are given by Çankaya (2018) regarding the onset of fermentation are lower than the data obtained in this study.

\section{Coliform Bacteria}

The determination of coliform bacteria in şalgams was also carried out. Coliforms can be found in most foods and beverages. The presence of coliforms in food and beverages is an important indicator of poor and inadequate hygiene/sanitation and pasteurization conditions, and re- contamination after production and heat treatment (Çakır, 2000; Doğan et al., 2001).

In the study performed, the number of coliform bacteria was determined between 3.67-3.76 $\log \mathrm{CFU} / \mathrm{mL}$ and decreased with increasing acidity. Coliforms could not be isolated from the environment on the fourth day of fermentation in the samples with starter culture added, and on the fifth day of fermentation in the control.

Similarly, Çankaya (2018) reported that the number of coliform bacteria, which was between 3.12-3.42 log $\mathrm{CFU} / \mathrm{mL}$ at the beginning of fermentation, decreased over time in beverages produced by the direct process and, no samples were found at the end of the 8th day of fermentation. Tangüler (2010) determined that the number of coliform bacteria in şalgams produced industrially by the direct process is between 2.5-3.1 $\log \mathrm{CFU} / \mathrm{mL}$ at the beginning of fermentation and between 1.2-2.2 log $\mathrm{CFU} / \mathrm{mL}$ at the end of fermentation. In the same study, he produced şalgams with different methods and reported that it was initially between $2.04 \log \mathrm{CFU} / \mathrm{mL}$ and $5.07 \mathrm{log}$ $\mathrm{CFU} / \mathrm{mL}$, and again decreased over time during fermentation. He also reported that şalgams produced by the direct process could not be isolated from the fermentation medium after the seventh day. The data obtained in this conducted study are following the values reported in previous studies and are different from those determined by Tangüler (2010) in samples taken from different companies.

\section{The General Composition of Şalgams}

The composition of the şalgams produced by the direct production process and the addition of starter culture with the addition of different sizes of carrots are given in Table 1.

Dry matter and ash contents of şalgam samples were determined between 21.4-24.7 g/L and 12-13.1 g/L, respectively. While the highest dry matter and ash were determined in the experiments with vertical cut purple carrot added, the lowest values were found in the control samples. It was found that the size of purple carrot and the use of starter in the production of şalgam caused an increase in dry matter and ash content and were also statistically significant $(\mathrm{P}<0,05)$. In studies conducted on shalgam beverage with different methods, the dry matter amount was determined between 16.9-37 g/L and the ash amount between 8.5-22.3 g/L (Canbaş and Fenercioğlu, 1984; Deryaoğlu, 1990; Özler, 1995; Yener, 1997; Miişoğlu, 2004; Nesanır, 2004; Erten et al., 2008; Güneş, 2008; Ağırman, 2014; Gök, 2017).

LAB, which is effective in şalgam fermentation, is divided into two groups, which are homo-fermentative and hetero-fermentative LAB. Homo-fermentative LAB forms lactic acid at a high rate due to their metabolism, while hetero-fermentative $\mathrm{LAB}$ forms volatile acids such as acetic and propionic acid as well as lactic acid (Utuş 2008; Tangüler, 2010). The amount of volatile acid in the şalgam samples varies between $0.69-0.83 \mathrm{~g} / \mathrm{L}$ and it is seen that it increases with purple carrots used horizontally (Table 1). However, it can be said that the use of autochthonous starter culture increases the amount of volatile acid. The size of the purple carrot used and the use of starter are statistically significant at a 5\% significance level in terms of volatile acid. According to the TS 11149 standard, it is reported that the amount of volatile acid in ready-to-eat şalgams should be between 0.7-1.2 g/L (TSE, 2003). 
Table 1. General Composition of Shalgams

\begin{tabular}{|c|c|c|c|c|}
\hline General composition & $\mathrm{K}$ & S1 & S2 & Level of Importance \\
\hline Dry matter $(\mathrm{g} / \mathrm{L})$ & $21.44^{\mathrm{b}} \pm 1.4$ & $22.93^{\mathrm{a}} \pm 1.4$ & $24.73^{\mathrm{a}} \pm 0.8$ & $*$ \\
\hline $\operatorname{Ash}(g / L)$ & $12.02^{\mathrm{b}} \pm 0.1$ & $12.98^{\mathrm{a}} \pm 0.3$ & $13.06^{\mathrm{a}} \pm 0.0$ & $*$ \\
\hline Titratabe acidity $(\mathrm{g} / \mathrm{L})^{\mathrm{a}}$ & $6.16^{\mathrm{a}} \pm 0.2$ & $6.55^{\mathrm{a}} \pm 0.1$ & $6.29^{\mathrm{a}} \pm 0.1$ & $*$ \\
\hline $\mathrm{pH}$ & $3.40^{\mathrm{a}}$ & $3.37^{\mathrm{a}}$ & $3.39^{\mathrm{a}}$ & $*$ \\
\hline Volatile acidity $(\mathrm{g} / \mathrm{L})^{\mathrm{b}}$ & $0.69^{\mathrm{a}} \pm 0.1$ & $0.83^{\mathrm{a}}$ & $0.74^{\mathrm{a}}$ & $*$ \\
\hline Total sugar (mg/L) & $751^{\mathrm{a}} \pm 140$ & $539^{b} \pm 160$ & $538^{\mathrm{b}} \pm 76$ & $*$ \\
\hline Salt $(\mathrm{g} / \mathrm{L})$ & $10.04^{\mathrm{a}} \pm 0.3$ & $10.72^{\mathrm{a}} \pm 0.8$ & $10.67^{\mathrm{a}} \pm 0.3$ & $*$ \\
\hline Total phenol $\left(\mathrm{OY}_{280}\right)$ & $21.17^{\mathrm{a}} \pm 2$ & $19.49^{\mathrm{a}} \pm 3$ & $19.96^{a} \pm 3$ & $*$ \\
\hline Total anthocyanin $(\mathrm{mg} / \mathrm{L})$ & $133^{\mathrm{b}} \pm 4$ & $171^{\mathrm{a}} \pm 22$ & $161^{\mathrm{a}} \pm 14$ & $*$ \\
\hline
\end{tabular}

The difference between values shown by different letters on the same row is statistically significant ( $\mathrm{P} \leq 0.05)$, In terms of lactic acid, ${ }^{\mathrm{b}}$ in terms of acetic acid

Therefore, the values determined in the study are generally compatible with those reported in the standard and previous studies (Utuş, 2008; Tangüler, 2010). However, it is higher than the values $(0.31-0.39 \mathrm{~g} / \mathrm{L})$ reported by Ağırman (2014).

As can be seen from Table 1, the total amount of sugar and salt in şalgams were found between $538-751 \mathrm{mg} / \mathrm{L}$ and $10-11 \mathrm{~g} / \mathrm{L}$, respectively. Moreover, in the analysis of variance, a statistically significant difference was found between the samples in terms of total sugar and salt amounts at a $5 \%$ significance level $(\mathrm{P} \geq 0.05)$. In studies conducted on shalgam beverage with different methods, the total sugar content was found to be between 0.09-0.99 g/L (Utuş, 2008; Güneş, 2008; Tangüler, 2010; Ağırman, 2014) and the salt amount between 8.2-20.90 g/L (Deryaoğlu, 1990; Özler, 1995; Yener, 1997; Özhan, 2000; Güneş, 2008; Ağırman, 2014; Gök, 2017). Çankaya (2018) reported that the total sugar amount in şalgams was higher (between 4.85-5.64 g/L) in a study conducted with the direct production process at different temperatures. It has been reported that the reason for this is the premature termination of fermentation. However, the data obtained in this study were found to be compatible with the other studies mentioned above.

Generally, a healthy adult needs 10 to 20 grams of salt per day. If it is not taken from other sources, consuming a glass (approximately $200 \mathrm{~mL}$ ) of şalgam daily will provide a significant portion of the salt needed. Otherwise, health problems may likely occur due to the high salt content of this product as a result of the high consumption of şalgam along with other sources (Sencer, 1983; Tangüler, 2010). For this reason, it should be consumed carefully and studies are carried out to reduce the amount of salt in the şalgam (Ağırman, 2014).

Total phenols are compounds found in very low amounts in various fruits/vegetables, and they contain compounds such as phenol acids, flavonoids, tannins and anthocyanins. Anthocyanins, which are soluble natural colour pigments, are present in abundant amounts in black carrots (Ribéreau-Gayon et al., 2006) and give the şalgam its distinctive red colour (Canbaş and Deryaoğlu, 1993; Erten et al., 2008).

Total phenol $\left(\mathrm{OY}_{280}\right)$ was determined the most in the control sample (21.2), while the lowest was determined in the sample (19.5) in which purple carrot was added. In contrast, the total amount of anthocyanin in terms of cyanidin-3-glycoside was found to be the highest $171 \mathrm{mg} / \mathrm{L}$ in the horizontal cut purple carrot added sample and the lowest $133 \mathrm{mg} / \mathrm{L}$ in the control sample. The effects of $L$. plantarum addition and purple carrot size on total phenol and total anthocyanin amounts were found to be statistically significant. In previous studies in şalgams, total phenol (OY280) was determined between 20.7-36.4 and anthocyanin amounts between 88.3-238 mg/L (Nesanır, 2004; Güneş, 2008; Utuş, 2008; Ağırman, 2014). The data obtained in the study performed are consistent with previous studies except for the S1 sample (amount of anthocyanin).

The important results obtained in this study, which examined the effect of $L$. plantarum and different size purple carrot quality on the quality of turnip drink, can be expressed as follows. In the experiments performed using a starter culture, it was determined that $\mathrm{LAB}$ adapted to the environment more easily, started fermentation rapidly and increased total acidity rapidly.

However, there are no significant differences between the use of $4 \mathrm{~cm}$ horizontal and $12 \mathrm{~cm}$ vertical cut purple carrots. However, it can be said that the use of horizontally cut carrots is more important, especially in terms of total acidity. In conclusion, the use of horizontally cut purple carrots in shalgam beverage production and L. plantarum as an autochthonous starter is recommended, but more detailed studies are required on this subject.

\section{Thanks}

For their contribution to the study, we thank Assoc. Dr. Adnan BOZDOĞAN and MSc. Eren Kemal Balıkçı

\section{Conflict of Interest}

The author declares that there is no conflict of interest

\section{References}

Ağırman B. 2014. Şalgam Suyu Üretiminde Farklı Klorür Tuzları Kullanılarak Sodyum Klorür Miktarının Azaltılması. Yüksek Lisans Tezi, Çukurova Üniversitesi, Fen Bilimleri Enstitüsü, 115S, Adana, Türkiye.

Aktan N, Yücel U, Kalkan H. 1998. Turşu Teknolojisi. Ege Üniversitesi Ege Meslek Yüksek Okulu Yayınları, No: 23, Ege Üniversitesi Basımevi, İzmir, s. 138.

Altay F, Kabancioglu-Guler F, Daskaya-Dikmen C, Heperkan D. 2013. A review on traditional Turkish fermented non-alcoholic beverages: Microbiota, fermentation process and quality characteristics. International Journal of Food Microbiology, 167: 44-56. doi: 10.1016/j.ijfoodmicro. 2013.06.016

Amrane A, Prigent Y. 1996. Behaviour of the yeast Kluyveromyces marxianus var. marxianus during its autolysis. Antonie van Leeuwenhoek, 69: 267-272. https://doi.org/10.1007/BF00399615 
AOAC, 1990. Official Methods of Analysis of the Association of Official Analytical Chemists. Hekrich K (chief Ed.), Vol: 1 and Vol:2, 15th edn, Arlington, Virginia 22201 USA.

Arıc1 M. 2004. Mikrobiologische und chemische eigenschaften von salgam, Ernahrungs-Umschau, 51: 10-11.

Aydar A. 2003. Şalgam Suyu Üretiminde Lactobacillus plantarum ilavesinin Ürün Bileşim ve Kalitesine Etkileri. Yüksek Lisans Tezi, Trakya Üniversitesi, Fen Bilimleri Enstitüsü Gıda Mühendisliği Anabilim Dalı, 35S, Tekirdağ, Türkiye.

Barath A, Corsetti A, Halasz A, Gelencser E. 1999. New Aspect for Selection Criteria of Lactic Acid Starter Cultures. In: Proceedings of Euro Food Chemistry X, 22-24 September, Budapest, Hungary, FECS-Event No:234, Vol, 1, pp. 37-45,

Baschali A, Tsakalidou E, Kyriacou A, Karavasiloglou A, Matalas A-L. 2017. Traditional low-alcoholic and nonalcoholic fermented beverages consumed in European countries: a neglected food group. Nutrition Research Reviews, 30: 1-24. doi:10,1017/S0954422416000202

Bircan S. 2013. Şalgam Suyundan İzole Edilen Bazı Laktik Asit Bakterilerinin Moleküler Karakterizasyonu ve Bunların Starter Kültür Olarak Kullanılma Potansiyellerinin Belirlenmesi. Yüksek Lisans Tezi, Çukurova Üniversitesi, Fen Bilimleri Enstitüsü, 93S, Adana, Türkiye.

Blandino A, Al-Aseeri ME, Pandiella SS, Cantero D, Webb C. 2003. Cereal-based fermented foods and beverages. Food Research International, 36: 527-543. doi: 10.1016/S09639969(03)00009-7

Canbaş A, Deryaoğlu A. 1993. Şalgam suyunun üretim tekniği ve bileşimi üzerinde bir araştırma. Doğa-Turkish Journal of Agricultural and Forestry, 17: 119-129.

Canbaş A, Fenercioğlu H. 1984. Şalgam suyu üzerine bir araştırma. Gıda Dergisi, 9(5): 279-286.

Caplice E, Fitzgerald GF. 1999. Food Fermentations: Role of microorganisms in food production and preservation. International Journal of Food Microbiology, 50: 131-149. https://doi.org/10.1016/S0168-1605(99)00082-3

Catley BJ. 1988. Isolation and Analysis of Cell Walls. In: Campbell I, Duffus JH (editors). Yeast, A Practical Approach. IRL Press, England, 289 p. https://doi.org/10.1042/bst0161097

Çakır İ. 2000. Koliform Bakteriler ve E. coli, Gıda Mikrobiyolojisi ve Uygulamaları. Ankara Üniversitesi Ziraat Fakültesi Gıda Mühendisliği Bölümü yayını. Genişletilmiş 2. Baskı. Sim Matbaacılık Ltd. Şti. İkinci Baskı, Ankara, $522 \mathrm{~s}$.

Çakır P. 2011. Ülkemizde Üretilen Şalgam Sularının bileşimleri ve Gıda Mevzuatına Uygunlukları Üzerine Bir Araştırma. Yüksek Lisans Tezi, Namık Kemal Üniversitesi, Fen Bilimleri Enstitüsü, 53S, Türkiye.

Çankaya A. 2018. Şalgam Suyunun Antioksidan Aktivite, Antosiyanin ve Fenolik Bileşikleri Üzerine Farklı Fermantasyon Sicaklığ 1 ve Üretim Yönteminin Etkisi. Yüksek Lisans Tezi, Niğde Ömer Halisdemir Üniversitesi, Fen Bilimleri Enstitüsü, 80S, Niğde, Türkiye.

Deryaoğlu A. 1990. Şalgam Suyu Üretimi ve Bileşimi Üzerine Bir Araştırma. Yüksek Lisans Tezi, Çukurova Üniversitesi Fen Bilimleri Enstitüsü, 57S, Adana, Türkiye.

Doğan HB, Tükel Ç. 2000. Toplam Aerobik Mezofilik Bakteri, İçinde: Gıda Mikrobiyolojisi ve Uygulamaları. Ankara Üniversitesi Ziraat Fakültesi Gıda Mühendisliği Bölümü yayını. Genişletilmiş 2. Baskı. Sim Matbaacılık Ltd. Şti. İkinci Bask1, Ankara, $522 \mathrm{~s}$.

Doğan HB, Çakır İ, Keven F, Coşansu S, Kıral N, Dağer Tİ, Gürsu G, Halkman AK. 2001. Çeşitli gıdalarda koliform, fekal koliform ve E. coli varlığı. Gıda, 26(2): 83-90.

Erginkaya Z, Hammes WP. 1992. Şalgam suyu fermantasyonu sırasında mikroorganizmaların gelişimi ve izole edilen laktik asit bakterilerinin tanımlamaları üzerine bir araştırma. Gıda, 17: 311-314.
Erten H, Tanguler H, Canbaş A. 2008. A traditional Turkish lactic acid fermented beverage: Shalgam (şalgam). Food Reviews International, 24: 352-359. doi: 10.1080/8755912080208932 4

Erten H, Tanguler H. 2012. Şalgam (Salgam). In: Hui YH, Evranuz EÖ (editors). Handbook of Plant-Based Fermented Food and Beverage Technology. 2nd, Press CRS Press, London-New York, pp. 657-664. ISBN: 9780429106798

Garcia C, Guerin M, Souidi K, Remize F. 2020. Lactic fermented fruit or vegetable juices: past, present and future. Beverages, 6(8): 1-32. doi: 10.3390/beverages6010008

Gassem MAA. 2002. A Microbiological study of sobia: A fermented beverage in the western province of Saudi Arabia. World Journal of Microbiology and Biotechnology, 18: 173177. doi: 10.1023/A:1014916702466

Gök S. 2017. Adana Ilinde Satışa Sunulan Şalgam Sularının Kalite Özelliklerinin ve Türk Gıda Kodeksine Uygunluğunun Belirlenmesi. Yüksek Lisans Tezi, Kahramanmaraş Sütçü İmam Üniversitesi Fen Bilimleri Enstitüsü, 60S, Kahramanmaraş, Türkiye.

Güneş G, 2008. Şalgam Suyu Üretiminde En Uygun Siyah Havuç (Daucus carota) Miktarının Belirlenmesi Üzerine Bir Araştırma. Yüksek Lisans Tezi, Ç.Ü. Fen Bilimleri Enstitüsü, Gıda Mühendisliği Anabilim Dalı, 48S, Adana, Türkiye.

Halkman AK. 2005. Gida Mikrobiyolojisi Uygulamaları. Merck, Başak Matbaacılık ve Tanıtım Hizmetleri Ltd. Şti. 358 s, Ankara.

Ignat MV, Salantă LC, Pop OL, Pop CR, Tofană M, Mudura E, Coldea TE, Bors A, Pasqualone A. 2020. Current functionality and potential improvements of non-alcoholic fermented cereal beverages. Foods, 9(1031): 1-28. doi:10,3390/foods 9081031

İyiçınar H. 2007. Kontrollü Şartlarda Şalgam Suyu Üretimi Üzerine Farklı Formülasyonların Etkisi. Yüksek Lisans Tezi, Selçuk Üniversitesi Fen Bilimleri Enstitüsü, 58S, Konya, Türkiye.

Kabak B, Dobson AD. 2011. An introduction to the traditional fermented foods and beverages of Turkey. Critical Reviews in Food Science and Nutrition, 51(3): 248-60. doi: 10.1080/10408390903569640

Koksoy A, Kilic M. 2004. Use of hydrocolloids in textural stabilization of a yoghurt drink, ayran. Food Hydrocolloids, 18:593-600. doi: 10.1016/j.foodhyd.2003.10.002

Mishra SS, Ray RC, Panda SK, Montet D. 2017. Technological Innovations in Processing of Fermented Foods an Overview, In: Ray RC, Montet D (Editors). Fermented Foods, Part II: Technological Intervention. CRC Press, Boca Raton, pp. 2145. eBook ISBN 9781315205359

Naidu AS, Bidlack WR, Clemens RA. 1999. Probiotic spectra of lactic acid bacteria (LAB). Critical Reviews in Food Science and Nutrition, 38(1): 13-126. doi: 10.1080/10408699991279187

Nesanir M. 2004. Şalgam Suyunu Berraklaştırma Olanakları. Yüksek Lisans Tezi, Harran Üniversitesi Fen Bilimleri Enstitüsü, Gıda Mühendisliği Anabilim Dalı, 59S, Şanlıurfa, Türkiye.

Ough CS, Amerine MA. 1988. Methods for Analysis of Musts and Wines. John Wiley and Sons, New York, 400p. ISBN: 978-0-471-62757-9

Özhan N. 2000. Şalgam Suyunda Escherichia coli'nin Yaşama Süresinin Bulunması. Yüksek Lisans Tezi, Mersin Üniversitesi Fen Bilimleri Enstitüsü, Gıda Mühendisliği Anabilim Dalı, 47S, Mersin, Türkiye.

Özler N. 1995. Şalgam Suyu Üretiminde Araştırmalar. Yüksek Lisans Tezi, Uludağ Üniversitesi Fen Bilimleri Enstitüsü, 57S, Bursa, Türkiye,

Öztürk O. 2009. Adana Piyasasındaki Şalgam Sularının Bileşimleri Üzerine Bir Araştırma. Yüksek Lisans Tezi, Çukurova Üniversitesi, Fen Bilimleri Enstitüsü, Gıda Mühendisliği Ana Bilim Dalı, 43S, Adana, Türkiye. 
Ribéreau-Gayon P, Glories Y, Maujean A, Dubourdieau D. 2006. Handbook of Enology, the Chemistry of Wine and Stabilization and Treatments. John Wiley and Sons, Ltd, Volume 2, 2nd Edition, 434. ISBN 9780470010396

Sencer E. 1983. Beslenme ve Diyet. İstanbul Üniversitesi T1p Fakültesi Vakfi. Bayda Yayın No: 4, İstanbul, $404 \mathrm{~s}$.

Tangüler H. 2010. Şalgam suyu üretiminde etkili olan laktik asit bakterilerinin belirlenmesi ve şalgam suyu üretim tekniğinin geliştirilmesi. Doktora Tezi (PhD Dissertation). Çukurova Üniversitesi Fen Bilimleri Enstitüsü, 367S, Adana, Türkiye.

Tanguler H, Ağırman B. 2020. Şalgam Suyu Üretimi. In: Erkmen $\mathrm{O}$, Erten H, Sağlam H. (editors). Fermente Ürünler Teknolojisi ve Mikrobiyolojisi. Nobel Akademik Yayıncılık, pp. 511-530. ISBN 978-625-406-665-8, 862

Tangüler H, Dinç SÖ, Beylikci SC. 2020. Problems, Suggestions and Last Trends Related to Salgam Beverage which is Traditional Product of Turkey, Turkish Journal of Agriculture - Food Science and Technology, 8(6): 1266-1271. doi: 10.24925/turjaf.v8i6.1266-1271.3266

Tangüler H, Erten H. 2012. Occurrence and growth of lactic acid bacteria species during the fermentation of shalgam (salgam), a traditional Turkish fermented beverage. LWT-Food Science and Technology, 46: 36-41. doi: 10.1016/j.lwt.2011.10.026
Tanguler H, Erten H. 2013. Selection of potential autochthonous starter cultures through lactic acid bacteria isolated and identificated from salgam: A traditional Turkish fermented beverage. Turkish Journal of Agriculture and Forestry, 37: 212-220. doi: 10.3906/tar-1205-37

TS 11149, 2003. Şalgam suyu. Türk Standartları Enstitüsü, Ankara, Kasım.

Utuş D. 2008. Şalgam Suyu Üretiminde Kullanılan Siyah Havuç (Daucus carota) Boyutunun Şalgam Suyu Kalitesi Üzerine Etkisi. Yüksek Lisans Tezi, Çukurova Üniversitesi, Fen Bilimleri Enstitüsü, Biyoteknoloji Anabilim Dalı, 55S, Adana, Türkiye.

Veiga M, Costa EM, Voss G, Silva S, Pintado M. 2019. Engineering and Health Benefits of Fruits and Vegetables Beverages. In: Grumezescu AM, Holban AM (editors). NonAlcoholic Beverages, the Science of Beverages. Duxford, United Kingdom, Elsevier, Vol (6), 559 p. eBook ISBN 9780128157022

Wrolstad RE. 1976. Color and Pigment Analyses in Fruit Products, Station Bulletin 624, Agricultural Experiment Station Oregon, Oregon State University, Corvallis.

Yener D. 1997. Mersin İl Merkezinde Değişik Satış Yerlerinden Alınan Şalgam Suyu Örneklerinin Fiziksel, Kimyasal, Duyusal ve Mikrobiyolojik Özellikleri Üzerine Bir Araştırma. Yüksek Lisans Tezi, Trakya Üniversitesi Fen Bilimleri Enstitüsü, 45S, Tekirdağ, Türkiye 